\title{
Zorg voor jeugd met beleid
}

De Jeugdgezondheidszorg (JGZ) komt bij de uitoefening van haar preventietaken steeds vaker collega's tegen van de Jeugdzorg, Jeugdwelzijnszorg, Jeugd Geestelijke Gezondheidszorg (GGZ) en zorg voor jeugd met een licht verstandelijke beperking (LVB). Al deze partners in de zorg voor jeugd maken zich op voor een grote metamorfose, de zogenaamde transitie en transformatie van de Jeugdzorg. Het gaat niet om een kosmetische verandering. De structuur van de zorg gaat in het geheel op de schop. Er komt een stelselherziening aan waarbij de gemeente verantwoordelijk wordt voor tal van jeugddomeinen. De Jeugdgezondheidszorg en Jeugdwelzijnszorg zijn van oudsher al een taak van gemeenten. Ook voor onderwijsvoorzieningen hebben gemeenten aandacht. Daar komen de Jeugdzorg, Jeugd-GGZ en Jeugd-LVB bij. De door provincies en stadsregio's aangestuurde Bureaus Jeugdzorg gaan verdwijnen. Dit betekent dat het stelsel van indicatiestelling verandert. Zowel de verplichte Jeugdbescherming als vrijwillige Jeugdzorg, Jeugd-GGZ en Jeugd-LVB komen in één bestuurlijk kader, waarover de gemeenten, soms op bovengemeentelijk niveau, het beleid bepalen. Behalve de bestuurlijke en organisatorische transitie staat de overheid een zorginhoudelijke transformatie voor die tot kwaliteitsverbetering in de zorg voor jeugd moet leiden.

De verandering in de zorg voor jeugd is ingegeven door vele motieven. Het beroep dat wordt gedaan op de Jeugdzorg en Jeugd-GGZ stijgt fors, terwijl er geen aanwijzingen zijn dat het aantal kinderen met ernstige gedrags- en emotionele problemen sterk toeneemt. Uit een recente studie naar de prevalentie van kindermishandeling in Nederland blijkt bijvoorbeeld dat er niet zozeer aanwijzingen zijn dat de prevalentie van kindermishandeling in vijf jaar tijd is toegenomen, maar wel dat het aantal gesignaleerde gevallen en meldingen bij Advies- en Meldpunten Kindermishandeling (AMK) is gestegen. ${ }^{1}$ Ouders en hulpverleners zijn alerter op problemen bij kinderen, maar dat het slecht gaat met het Nederlandse kind wordt niet bevestigd met cijfers. Echter, door het grote beroep op de jeugdvoorzieningen is een aantal tekortkomingen in de zorgstructuur bloot komen te liggen. De Werkgroep Toekomstverkenning Jeugdzorg van de Tweede Kamer, bestaande uit vertegenwoordigers van alle politieke partijen, constateerde in een rapport de volgende knelpunten: "problemen als van het kastje naar de muur verwezen worden, lange wachttijden, teveel hulpverleners die werken binnen éen gezin, te weinig tijd voor daadwerkelijke zorg aan het kind, nog te weinig bewezen effectieve behandelmethoden die worden toegepast, grote regel- en verantwoordingsdruk voor de werkers en teveel en te complexe en gescheiden financieringsstromen". 2 Het zal daarom niet verbazen dat de zorg voor jeugd in de aandacht staat van de politiek. Wat opvalt is dat de politieke partijen eensgezind zijn in hun kritiek op het functioneren van de zorg voor jeugd en aankoersen op minder bureaucratie in de zorg en herstel van het vertrouwen van burgers in de professionaliteit van de hulpverlener. Dit heeft geresulteerd in de plannen voor een stelselherziening. Ook hier valt op dat Rijk, provincies en gemeenten eensgezind, schouder aan schouder, werken aan het realiseren van de stelselwijziging. Hun ambitie is vastgesteld in een bestuursakkoord en een agenda die loopt tot en met 2015 .

Wat gaan burgers en professionals van deze transitie en transformatie merken? Dat hangt allereerst af van de nieuw te vormen regering. Omdat de wens tot verbetering van de Jeugdzorg kamerbreed wordt gedeeld is het vrijwel zeker dat het plan voor transitie en transformatie in een of andere vorm doorgang vindt. Of daar bijvoorbeeld ook de AWBZ-gefinancierde Jeugd-GGZ onder blijft vallen, zoals nu het plan is, zal nog moeten blijken. De Structuurnota van Staatssecretaris Hendriks van 1974 stelde op het gebied van de gezondheidszorg ook een dergelijke grootscheeps decentralisatieplan voor. Van de plannen voor regionale sturing door gemeenten en gewesten kwam uiteindelijk niet veel terecht. Maar de Structuurnota had wel een belangrijke invloed op de ordening van de gezondheidszorg, waaruit onder andere publieke taken op het terrein van preventie werden samengebracht in de basisgezondheidszorg. Echter, de zorgverzekeraars wonnen uiteindelijk het getouwtrek om de macht. Niet de lagere overheid, maar de financier stuurt de eerstelijns- en ziekenhuiszorg aan. Anno 2012 zal na de verkiezingen moeten blijken of de transitie en transformatie in de zorg voor jeugd in de omvang zoals nu gepland doorgang vindt.

Wat er van alle plannen ook terecht komt, de burger zal hoe dan ook iets gaan merken van vernieuwing in de zorg voor jeugd. In alle gemeenten in Nederland zijn Centra voor Jeugd en Gezin (CJG) operationeel. Zij vormen zich om tot frontoffice voor de zorg voor jeugd. De verantwoordelijkheid voor het opgroeien van het kind ligt bij het gezin, maar als het niet lukt moet het CJG zo snel mogelijk hulp inschakelen, zo is de nieuwe zienswijze. Ook dan blijft de opvoeder, voor zover nog mogelijk, verantwoordelijk voor het kind, en zo hoort het ook. Dit moet ervoor gaan zorgen dat onder andere JGZ, maatschappelijk werk en Jeugdzorg in het CJG in afstemming met elkaar hulp gaan aanbieden, waardoor kind en ver- 
zorger niet van het kastje naar de muur worden gestuurd. In de gemeenten zijn vele taskforces inmiddels bezig om handen en voeten te geven aan deze verandering.

De transformatie van de zorg voor jeugd gaat niet voorbij aan de medewerkers in de zorg. Bij hen is veel innovatiekracht zichtbaar. In de JGZ wordt bijvoorbeeld menskracht vrij gespeeld om in samenwerking met CJG-partners zorg te bieden aan kinderen en gezinnen met een complexe hulpvraag. In het CJG wordt druk geëxperimenteerd met onder andere triage in de zorg voor kinderen die extra zorg nodig hebben en kinderen die met minder aandacht toe kunnen, opvoedinterventies en ' 1 gezin 1 plan' methodieken. De transitieagenda tot 2015 zal te krap zijn om alle ambitieuze, maar gewenste veranderingen te realiseren. De echte verbetering zal pas merkbaar zijn wanneer de overheid erin is geslaagd te sturen op effectieve hulp aan het gezin. Wanneer problemen met het kind of in het gezin eerder worden gesignaleerd en opgelost, zodat zwaardere vormen van zorg worden voorkomen. Wanneer beroepsbeoefenaren zijn opgeleid die de complexe vragen van gezinnen aankunnen. Dit vraagt een goede onderbouwing met wetenschappelijk onderzoek en een maximale inspanning om de vernieuwing in de zorg te implementeren. Dit vraagt nog meer investering in een algehele kwaliteitsverbetering in de zorg voor jeugd, en ook veel tijd.

De structuurverandering in de zorg voor jeugd zal hand in hand moeten gaan met zorgvernieuwing: transitie én transfer. Aan de verre horizon gloren veranderingen in de zorg voor jeugd die winst opleveren voor de burger. Maar ondertussen is er de overvragende burger die het beste wil voor zijn kind met gezondheids-, opvoed- of gedragsproblemen. Fricties in de forse vraag van de consument en het renoverende zorgaanbod zullen de komende jaren onvermijdbaar zijn. De zorg voor jeugd staat voor een grote uitdaging om het gezin een veilig oord te blijven bieden, wanneer ouder en kind de problemen niet meer op eigen kracht kunnen overwinnen.

\section{Paul Kocken}

\section{LITERATU U R}

1. Alink L, IJzendoorn R van, Bakermans-Kranenburg M, Pannebakker F, Vogels T, Euser S. Kindermishandeling in Nederland anno 2010; de tweede nationale prevalentiestudie mishandeling van kinderen en jeugdigen (NPM-2010). Leiden: Universiteit Leiden, TNO, 2011.

2. Werkgroep Toekomstverkenning Jeugdzorg. Jeugdzorg dichterbij. Den Haag: Tweede Kamer, 2010.

\section{Uit de opleidingen}

Er gebeurt het nodige rond de basisopleidingen (geneeskunde, gezondheidswetenschappen, sociale wetenschappen) en vervolgopleidingen van professionals op het terrein van public health en occupational health dat de moeite waard is om met elkaar te delen. TSG wil ook hier ruimte bieden voor spreiding van informatie, inzichten, ervaringen en debat. We scheppen hier plaats voor binnen de rubriek Forum onder het kopje 'Uit de opleidingen'.

In dit nummer vindt u een eerste bijdrage over het probleem dat instroom in de vervolgopleidingen tot bedrijfsarts al enkele jaren zo gering is dat de beroepsgroep flink krimpt en de oplossingen waar het werkveld aan denkt. Dat is onder andere meer aandacht voor de arbeidsgeneeskunde in de medische opleidingen. Dat lukt alleen wanneer ook anderen (waaronder veel TSG lezers) er de schouders onder zetten.

De redactie van TSG nodigt betrokkenen nadrukkelijk uit om vergelijkbare bijdragen in te sturen. Op die manier kunnen we met elkaar de opleidingen versterken.

Namens de redactie van TSG

Joost van der Gulden, Johan Polder 